\title{
GROWTH RESPONSE OF GLIRICIDIA SEPIUM (Jacq.)Walp TO INOCULATION WITH DIFFERENT ARBUSCULAR MYCORRHIZAL (AM) FUNGI
}

\author{
K. Twum-Ampofo \\ Department of Agroforestry, \\ Faculty of Renewable Natural Resources, \\ Kwame Nkrumah University of Science and Technology, Kumasi, Ghana
}

\begin{abstract}
This study was conducted to assess the variation in performance of four arbuscular mycorrhizal fungi (Glomus clarum, Glomus etunicatum, Glomus intraradices, and Gigaspora rosea) with and without Rhizobium inoculation in promoting growth and nutrient ( $N$ and $P$ ) uptake in Gliricidia sepium. Gliricidia seedlings were grown in sterilised (autoclaved) vermiculite and sand mixture in 2:1 (v:v). Each week, plants received $50 \mathrm{~cm}^{3}$ of nutrient solution (with $N$ and $P$ additions) according to the treatments. The experimental design was a 4x2 factorial arranged in a randomised complete block design. Seedlings were harvested after 12 weeks. Dry weights of plant parts, nodulation, arbuscular mycorrhizal fungal colonization, nitrogen and phosphorus concentration and content were determined. AM fungi differed in their effectiveness in enhancing growth of Gliricidia sepium. Glomus clarum was most efficient and produced statistically higher total plant dry weight than other mycorrhizal fungi. Dual inoculation with AM fungi and Rhizobium was effective in promoting host plant growth over Rhizobium- uninoculated mycorrhizal plants in terms of leaf area, shoot and root dry weights, total plant biomass and shoot-root ratio. Rhizobium-inoculated Glomus clarum treatment recorded significantly higher (approximately a third fold increase) total plant dry weight, than the similar treatments of Glomus etunicatum, Glomus intraradices and Gigaspora rosea. Shoot-root ratio was statistically greater with mycorrhizal plants inoculated with Rhizobium than the non-Rhizobium inoculated treatments due to improved mineral nutrition particularly nitrogen (through nitrogen fixation). Nodulation assessed by the number of nodules produced per plant was statistically similar between the Rhizobium-inoculated mycorrhizal treatments but significantly higher than the Rhizobium- inoculated non-mycorrhizal comparison treatment. Plants inoculated with Glomus clarum and Glomus intraradices significantly achieved higher root colonization than Glomus etunicatum and Gigaspora rosea. Rhizobium inoculation reduced root colonization with all the Glomus species except Gigaspora rosea. A highly significant $(P<0.001)$ interaction between mycorrhiza and Rhizobium was observed for mycorrhiza root colonization. Rhizobium- inoculated treatments recorded significantly higher $N$ concentration and content over non-Rhizobium mycorrhizal plants supplied with combined nitrogen. Inoculation with Glomus clarum significantly increased P concentration and content in all plant parts. Gigaspora rosea was least effective in promoting phosphorus uptake. Arbuscular mycorrhiza fungi infection was positively correlated with $P$ concentration $(\% P)(r=0.74$, $P<0.01)$, and $P$ content $(m g P)(r=0.52, P<0.01)$. The study has shown the importance of some AM fungi for legume tree growth and nutrition and therefore in nutrient deficient soils, effective mycorrhizal fungus and Rhizobium could be used to promote growth and nitrogen fixation in $\mathrm{N}_{2}$-fixing tree seedlings.
\end{abstract}

Keywords: Growth, Gliricidia sepium, arbuscular mycorrhizal fungi, Rhizobium, phosphorus uptake

54 Journal of Science and Technology, Vol. 28, No. 2, August, 2008 


\section{INTRODUCTION}

Successful establishment of most tropical woody legumes depends on their ability to form symbiotic associations between their roots and beneficial microorganisms - rhizobia and mycorrhizas (Stahl et al., 1988; Barea et al., 1990; Herrera et al., 1993).

Different types of mycorrhizal fungi form associations with plant roots, but the arbuscular mycorrhizas are by far the most widespread type of mycorrhiza in nature (Harley and Smith, 1983) and are also the most commonly occurring on nodulated nitrogen fixing plants (Barea et al., 1992; Hayman, 1986; Roskoski et al., 1986).

Considerable interest has been generated in AM fungi because of the attributes they can confer to plants. Inoculation with AM fungi generally enhances plant growth by alleviating response to nutrient deficiency or other stresses and by enhancing $\mathrm{N}_{2}$-fixation process (Barea et al., 1990; Fitter and Garbaye, 1994; Mortimer et al., 2008). Growth promotion of Leucaena leucocephala when seedlings were inoculated with Glomus spp has been documented (Manjunath et al., 1984; Aziz and Habte, 1985; South and Habte, 1985; Manjunath et al., 1989). This has also been documented in nodulated plants of Acacia nilotica (Michelsen and Rosendahl, 1990). Habte and Turk, (1991) also observed that AM inoculation significantly stimulated dry matter accumulation in Cassia spectabilis (a non -nodulating legume) and Gliricidia sepium. Other positive growth responses to mycorrhizal inoculation of nitrogen-fixing trees have been reported for Sesbania grandiflora (L) Poir (Habte and Aziz, 1985; Aziz and Habte, 1989a) and Acacia auriculiformis A. Cunn ex Beth, Acacia mangium Wild and Albizia falcataria (L) Fosberg (Dela Cruz et al., 1988, 1990). It has also been shown that the growth promoting effect of AM fungi can equal phosphorus fertilization (Hayman, 1986; Azcón and Barea, 1992).

Significant growth enhancement of nodulated AM woody legumes is attributed to increased $\mathrm{N}$ and $\mathrm{P}$ concentrations and total $\mathrm{N}$ and $\mathrm{P}$ content
(Manjunath et al., 1984; Barea et al., 1990). Dela Cruz et al., (1988) observed significant positive correlation between $\mathrm{N}, \mathrm{P}$ concentration in tissues, total $\mathrm{N}$ and $\mathrm{P}$ content and acetylene reduction activity (ARA).

Arbuscular mycorrhizal fungi are known to be non-host specific (Barea and Azcón-Aquilar, 1983; Roskoski et al., 1986; Schenck, 1989). Despite the non-specificity of these fungi with respect to host plant, certain fungus-plant association are more efficient than others. Some species of AM fungi may enhance plant growth and nutrient uptake on some legume species and have little or no effect on others (Dela Cruz et al., 1988; Schenck, 1989; Ianson and Linderman, 1993; Pasqualini et al., 2007). Enhanced plant growth and nutrition in the AM-Rhizobium-legume tree symbiosis are related to the degree of the intersymbiont compatibility (Ruiz-Lozano and Azcón, 1993).

Studies have shown that Nitrogen fixing trees (NFTs) respond differently to inoculation with different strains of AM fungi (Aziz and Habte, 1989a; Aziz and Sylvia, 1993). Gliricidia sepium which is recently gaining attention of scientists and landuse practitioners (agroforesters) has little been studied with respect to its association with AM fungi as compared to Leucaena leucocephala.

The purpose of this study was to compare the variation in the efficiency of four AM fungi with and without Rhizobium inoculation in Gliricidia sepium in relation to plant growth and nutrient (N and $\mathrm{P}$ ) accumulation.

\section{MATERIALS AND METHODS \\ Growth Medium and Container}

Seedlings were grown in washed vermiculite and sand mixture in 2:1 (v:v). Growth medium and plastic pots with diameter of $11.5 \mathrm{~cm}$ and approximate volume of $750 \mathrm{~cm}^{3}$ were sterilised by autoclaving at $121^{\circ} \mathrm{C}$ at $101.3 \mathrm{kPa}$ for a minimum of 1 hour. Plants were grown in a greenhouse with an average day/night temperatures of $35 / 25$ $\pm 2{ }^{\circ} \mathrm{C}$. Pots were randomly arranged and rotated 
frequently within blocks to minimize positional effect. Each week plants were given $50 \mathrm{~cm}^{3}$ of nutrient solution with $\mathrm{N}$ and $\mathrm{P}$ additions according to the treatments. The chemical composition and quantities used are: $\mathrm{CaSO}_{4} .2 \mathrm{H}_{2} \mathrm{O}, 2.9 \mathrm{~mol}$ $\mathrm{m}^{-3} ; \mathrm{MgSO}_{4} .7 \mathrm{H}_{2} \mathrm{O}, 3.5 \mathrm{~mol} \mathrm{~m} \mathrm{~K}_{2} \mathrm{SO}_{4}, 0.51$ $\mathrm{mol} \mathrm{m} \mathrm{m}^{-3} ; \quad \mathrm{C}_{6} \mathrm{H}_{5} \mathrm{O}_{7} \mathrm{Fe} .5 \mathrm{H}_{2} \mathrm{O}, \quad 5.0 \mathrm{mmol} \mathrm{\textrm {m } ^ { - 3 }}$; $\mathrm{ZnSO}_{4} .7 \mathrm{H}_{2} \mathrm{O}, 0.1 \mathrm{mmol} \mathrm{m}{ }^{-3} ; \mathrm{H}_{3} \mathrm{BO}_{3}, 5.0 \mathrm{mmol}$ $\mathrm{m}^{-3} ; \mathrm{NaCl}, 1.0 \mathrm{mmol} \mathrm{m}^{-3} ; \mathrm{Na}_{2} \mathrm{MoO}_{4} .5 \mathrm{H}_{2} \mathrm{O}, 0.5$ $\mathrm{mmol} \mathrm{m}{ }^{-3} ; \mathrm{MnSO}_{4} \cdot 4 \mathrm{H}_{2} \mathrm{O}, 0.02 \mathrm{mmol} \mathrm{m}^{-3} ; \mathrm{Cu}-$ $\mathrm{SO}_{4} .5 \mathrm{H}_{2} \mathrm{O}, 0.1 \mathrm{mmol} \mathrm{m}{ }^{-3} ; \mathrm{CoSO}_{4} .7 \mathrm{H}_{2} \mathrm{O}, 0.02$ $\mathrm{mmol} \mathrm{m}{ }^{-3}$. The $\mathrm{pH}$ was adjusted to 6.0 using 1.0 $\mathrm{kmol} \mathrm{m}^{-3} \mathrm{NaOH}$ or $1.0 \mathrm{kmol} \mathrm{m}^{-3} \mathrm{HCl}$.

\section{Seeds and Seed Germination}

Seeds of Gliricidia sepium were obtained from Forestry Research Institute of Ghana (FORIG) Seed Unit. Prior to germination, uniform seeds were scarified with a piece of hot wire and surface sterilised with 3\% sodium hypochlorite $(\mathrm{NaOCl})$ solution for 3 minutes, rinsed several times in sterile distilled water and soaked for 4 hours to imbibe water. Seeds were then pregerminated on moist sterilised filter paper in Petri dishes and placed in an incubator at a temperature of $25^{\circ} \mathrm{C}$ to germinate. Viable seeds germinated after 48 hours. Germinated seeds with radicle length of $2-3 \mathrm{~cm}$ were planted in the pots. Seedlings were watered regularly to approximately field capacity, with sterile distilled water.

\section{Rhizobium Culture and Inoculation}

Rhizobium strain DUS 054 was obtained from the JIS Symbiosis laboratory (University of Dundee Rhizobium Collection). The strain was cultured in yeast-extract mannitol broth (YEMB) (Vincent, 1970). Germinated seeds were inoculated with $2 \mathrm{~cm}^{3}$ Rhizobium culture $\left(1 \times 10^{9}\right.$ cells $\mathrm{cm}^{-3}$ ) soon after planting.

\section{Arbuscular Mycorrhizal Fungi Inoculum and Inoculation}

Arbuscular mycorrhizal fungi used in the study were as follows: Glomus clarum Nicol.\& Schenck (BR148-1), Glomus etunicatum (BR149-3), Glomus intraradices Schenck \&
Smith (UT143-2) and Gigaspora rosea (FL1055). Pure single isolate cultures in the form of whole inoculum (consisting of growth medium, mycorrhizal roots and fungal propagules- spores, hyphae) were obtained from the International Collection of Arbuscular and VesicularArbuscular Mycorrhizal Fungi (INVAM) Centre. Plants were inoculated at the time of planting by placing $6 \mathrm{~g} \mathrm{pot}^{-1}$ of each fungus whole inoculum half way down each pot containing sterilised (autoclaved) growth medium.

\section{Experimental Design and Treatments}

The experimental design was randomised complete block with five replicates. Combinations of mycorrhiza with $(+\mathrm{R})$ or without (-R) Rhizobium inoculation were arranged in $4 \times 2$ factorial treatment design. Two sets of plants were left as controls; (a) Rhizobium inoculation only and (b) nonRhizobium, non-mycorrhizal (non-symbiotic) treatments. Non-Rhizobium (-R) inoculated plants were given mineral nitrogen $\left(3 \mathrm{~mol} \mathrm{~m} \mathrm{~m}^{-3} \mathrm{~N}\right.$ as $\mathrm{KNO}_{3}$ ) in their nutrient solution. All mycorrhiza fungus inoculated plants were supplied with 0.1 mol m${ }^{-3} \mathrm{P}$ as $\mathrm{KH}_{2} \mathrm{PO}_{4}$. The non-symbiotic and the other half of Rhizobium alone treatments had 0.2 mol $\mathrm{m}^{-3} \mathrm{P}$. Details of the treatments and their designations are as follows:

a) Rhizobium - uninoculated, mycorrhiza fungus treatments supplied with $3 \mathrm{~mol} \mathrm{~m}^{-3} \mathrm{~N}$ and 0.1 $\mathrm{mol} \mathrm{m} \mathrm{m}^{-3} \mathrm{P}$ (Ge-R, Gc-R, Gi-R, Gir-R).

b) Rhizobium - inoculated, mycorrhiza fungus treatments given $0.1 \mathrm{~mol} \mathrm{~m}^{-3} \mathrm{P}(\mathrm{Ge}+\mathrm{R}, \mathrm{Gc}+\mathrm{R}$, $\mathrm{Gi}+\mathrm{R}, \mathrm{Gir}+\mathrm{R})$.

c) Rhizobium - inoculated, non-mycorrhiza fungus treatment given $0.1 \mathrm{~mol} \mathrm{~m}^{-3} \mathrm{P}\left(\mathrm{R}+\mathrm{P}_{1}\right)$ and $0.2 \mathrm{~mol} \mathrm{~m}^{-3} \mathrm{P}\left(\mathrm{R}+\mathrm{P}_{2}\right)$.

d) Rhizobium - uninoculated, non-mycorrhiza (non-symbiotic) treatment supplied with $3 \mathrm{~mol}$ $\mathrm{m}^{-3} \mathrm{~N}$ and $0.2 \mathrm{~mol} \mathrm{~m}^{-3} \mathrm{P}\left(\mathrm{N}+\mathrm{P}_{2}\right)$.

Rhizobium-inoculated, non-mycorrhizal $\left(\mathrm{R}+\mathrm{P}_{2}\right)$ and non-symbiotic $\left(\mathrm{N}+\mathrm{P}_{2}\right)$ plants were termed as "comparison plants" instead of control plants. According to Bayne and Bethlenfalvay, (1987), such treatments lacking either or both microsym- 
biont and nutritionally supplemented with more or less equivalent amounts of $\mathrm{N}$ and /or $\mathrm{P}$ cannot be regarded as true controls in either form or function. The higher amount of $\mathrm{P}\left(0.2 \mathrm{~mol} \mathrm{~m}^{-3}\right)$ supplied to the comparison treatment plants $\left(\mathrm{R}+\mathrm{P}_{2} ; \mathrm{N}+\mathrm{P}_{2}\right)$ was to enable them achieve some physiological comparability with the AM fungi inoculated plants (Pascovsky et al., 1986; Pascovsky and Fuller, 1986).

\section{Plant Harvest}

Plants were harvested 12 weeks after planting (WAP). Harvested plants were separated into shoot, root and nodules. The shoot portion was cut off, weighed and put in a paper bag for drying. The root system were gently shaken and washed under running tap water. Nodules were removed, counted, weighed and put in a separate bag. For mycorrhizal assessment, approximately $1.5 \mathrm{~g}$ of roots were randomly sampled and stored in $50 \%$ alcohol at $4^{\circ} \mathrm{C}$ for assessment. Remaining roots were also weighed. Plant parts (shoots, roots, nodules) were dried to a constant weight at $70^{\circ} \mathrm{C}$ for $3-4$ days. The dry weight of the total root system were estimated from the fresh and dry weights of the "remainder" roots and the fresh weight of the sample for AM fungi assessment. Plant leaf area was determined using Delta $\mathrm{T}$ Area Meter (Delta-T Devices, Cambridge, UK).

\section{Mycorrhizal Assessment}

Mycorrhizal fungal infection was assessed by clearing and staining methods described by Phillips and Hayman, (1970) incorporating modifications from Koske and Gemma, (1989). Percentage colonization was estimated using the grid line intersect method (Giovanneti and Mosse, 1980). Root stored in 50\% alcohol were cut into $1 \mathrm{~cm}$ segments and spread in a plastic saucer whose base had 50 dots randomly marked. One hundred pieces were selected, rinsed several times in tap water to remove alcohol traces and then covered with $2.5 \%$ potassium hydroxide $(\mathrm{KOH})$. Roots and $\mathrm{KOH}$ are autoclaved at $121^{\circ} \mathrm{C}$ at $101.3 \mathrm{kPa}$ for 3 minutes. Af- ter cooling the roots were rinsed thoroughly under running tap water until no more brown colouring appears in the rising water. Roots were bleached with freshly prepared alkaline hydrogen peroxide $\left(3 \mathrm{~cm}^{3}\right.$ of ammonia in $30 \mathrm{~cm}^{3}$ and $3 \%$ hydrogen peroxide) for 30 minutes at room temperature and then roots were rinsed well in running tap water. Roots were acidified by soaking in $1 \% \mathrm{HCl}$ for an hour after which it was poured off and stained in acidic glycerol $\left(500 \mathrm{~cm}^{3}\right.$ glycerol, $50 \mathrm{~cm}^{3} 1 \% \mathrm{HCl}$ and $450 \mathrm{~cm}^{3} \mathrm{H}_{2} \mathrm{O}$ ) containing $0.05 \%$ trypan blue and autoclaved at $121^{\circ} \mathrm{C}$ at $101.3 \mathrm{kPa}$ for $3 \mathrm{~min}$ utes. The trypan blue solution was poured off and the roots stored in acidic glycerol till assessment. The staining process was carried out in a containerised staining apparatus devised by Classen and Zasoski, (1992).

Stained roots were spread over the base of a Petri dish so that no root obscured another and placed in another a petri dish marked with $12 \times 12 \mathrm{~cm}$ grid underneath. Using a stereo microscope vertical and horizontal grid lines were scanned and the presence or absence of infections (fungal structures- vesicles, arbuscules, or hyphae) was recorded at each point where the roots intersect a line. The percentage infections was calculated by dividing the number of infected points (presence) by total number of points (infected and uninfected) and multiplying by 100 .

\section{Nitrogen and Phosphorus Determination}

Plant materials for chemical analysis were ground in Glen Creston grinder to a fine consistency form (particle size $<0.5 \mathrm{~mm}$ ). Samples were weighed on Cahn Micro balance for nitrogen and phosphorus analysis. Nitrogen was determined using Carlo Erba Elemental Analyzer (Model 1106). Estimate of the total nitrogen in each sample was calculated from the percentage values obtained from the Elemental Analyzer.

Phosphorus was estimated using a variation of Vogel (1989) method modified by Baker (1992) and Jacob-Neto, (1993). Ground plant materials weighing $50 \pm 3 \mathrm{mg}$ were placed into a crucible covered with aluminium foil. Samples were ashed 
in a muffle furnace at a temperature of $550^{\circ} \mathrm{C}$ for 4 hours. To achieve complete combustion, temperatures between $200^{\circ} \mathrm{C}$ and $300^{\circ} \mathrm{C}$ were slowly increased (approximately $1^{\circ} \mathrm{C}$ per minute). Cooled ashed samples were dissolved in $3-5 \mathrm{~cm}^{3}$ of $2 \mathrm{kmol} \mathrm{m}^{-3} \mathrm{HCl}$ and the supernatant used in the phosphorus assay. Ammonium molybdate and ammonium metavanadate solutions were prepared by dissolving $10 \mathrm{~g}$ of ammonium molybdate salt in $160 \mathrm{~cm}^{3}$ and $500 \mathrm{mg}$ of ammonium metavanadate in $120 \mathrm{~cm}^{3}$ of distilled water in separate flask respectively. Bartons reagent was prepared by adding $50 \mathrm{~cm}^{3}$ concentrated nitric acid to ammonium metavanade solution, followed by ammonium molybdate solution and $70 \mathrm{~cm}^{3}$ of distilled water. Phosphorus standards between $0-70 \mu \mathrm{g} \mathrm{cm}^{-3}$ were prepared by dissolving previously dried $\mathrm{KH}_{2} \mathrm{PO}_{4}$ in $2 \mathrm{kmol} \mathrm{m}^{-3} \mathrm{HCl}$. Phosphorus was determined by pipetting 0.04 $\mathrm{cm}^{3}$ of $\mathrm{HCl}$ aliquot into a cuvette followed by $0.86 \mathrm{~cm}^{3}$ of distilled water and $0.1 \mathrm{~cm}^{3}$ of Bartons reagent. The cuvette was briefly shaken and left to stand for one hour after which the absorbance measured in a waveband of $450 \mathrm{~nm}$ using Gallenkamp Visi-Spec Spectrophotometer. The phosphorus standards were assayed in the same manner and a standard curve drawn. Phosphorus content in each sample was estimated by the standard curve

\section{Data Analysis}

Data were subjected to analysis of variance (ANOVA) using Statgraphics 5 and treatment means compared by Duncan's Multiple Range Test (DMRT) at $\mathrm{P} \leq 0.05$. Two sets of analyses were performed; (a) 4x2 factorial form with 4 AM fungi and 2 Rhizobium treatments (present, $+\mathrm{R}$; absent, -R) and (b) a one-way analysis with 10 treatments (4 AM fungi with and without Rhizobium), Rhizobium-inoculated, nonmycorrhizal treatment given $0.2 \mathrm{~mol} \mathrm{~m} \mathrm{~m}^{-3} \mathrm{P}$ $\left(\mathrm{R}+\mathrm{P}_{2}\right)$ and non-symbiotic treatment supplied with $3 \mathrm{~mol} \mathrm{~m}^{-3} \mathrm{~N}$ plus $0.2 \mathrm{~mol} \mathrm{~m}^{-3} \mathrm{P}\left(\mathrm{N}+\mathrm{P}_{2}\right)$. The Rhizobium-inoculated non-mycorrhizal treatment which received $0.1 \mathrm{~mol} \mathrm{~m}{ }^{-3} \mathrm{P}\left(\mathrm{R}+\mathrm{P}_{1}\right.$, true control) was discarded following mycorrhizal contamination of 3 replicates. However, the analyses permitted the evaluation of AM fungi with and without Rhizobium and also with the comparison plants $\left(\mathrm{R}+\mathrm{P}_{2} ; \mathrm{N}+\mathrm{P}_{2}\right)$. Data on percentage mycorrhizal root infection were subjected to arcsine transformation prior analysis.

\section{RESULTS}

Root colonization of the Rhizobium- inoculated Gliricidia sepium plants by different AM fungi $(\mathrm{Ge}+\mathrm{R} ; \mathrm{Gc}+\mathrm{R} ; \mathrm{Gi}+\mathrm{R}$; Gir+R) resulted in higher dry matter yield than the Rhizobium- uninoculated mycorrhizal plants (Ge-R; Gc-R; Gi-R; Gir-R) (Table 1). Rhizobium- inoculated Glomus clarum treatment $(\mathrm{Gc}+\mathrm{R})$ recorded significantly higher total plant dry weight, approximately a third fold increase, than the Rhizobium-inoculated Glomus etunicatum (Ge+R), Rhizobium- inoculated Glomus intraradices ( $\mathrm{Gi}+\mathrm{R})$, and Rhizobiuminoculated Gigaspora rosea (Gir+R) treatments. Glomus clarum in association with Rhizobium $(\mathrm{Gc}+\mathrm{R})$ was the only treatment which recorded significantly higher dry weight than its uninoculated counterpart (Gc-R). Gc+R treatment obtained higher but statistically similar total plant dry weight than the Rhizobium-inoculated nonmycorrhizal comparison plants $\left(\mathrm{R}+\mathrm{P}_{2}\right)$ (Table 1$)$. No significant variation in shoot, root, and total plant dry weight was observed between the Rhizobium- uninoculated mycorrhizal plants and the non-symbiotic comparison plants $\left(\mathrm{N}+\mathrm{P}_{2}\right)$. Analysis of variance for the main effects (mycorrhiza and Rhizobium) on dry matter produced (Table 2) indicates that Glomus clarum (Gc) was most efficient and produced statistically higher total plant dry weight than the other mycorrhizal fungi. Significant variation in growth (leaf area, shoot, root, and total plant dry weight) was also observed between plants inoculated with Rhizobium (+R) and those that did not receive Rhizobium inoculum (-R) treatments (Table 2).

Shoot-root ratio was statistically greater with mycorrhizal plants inoculated with Rhizobium (+R) than non-Rhizobium (-R) treatments (Table 1). Main effects analyses for shoot-root ratio were 
Table 1: Growth characteristics of G. sepium inoculated with different arbuscular mycorrhizal fungi with (+) and without (-) Rhizobium (R) inoculation and fertilised comparison plants at 12 weeks after planting (WAP).

\begin{tabular}{llllll}
\hline Treatments & $\begin{array}{l}\text { Leaf area } \\
\left(\mathbf{c m}^{2}\right)\end{array}$ & $\begin{array}{l}\text { Shoot } \\
\text { dry wt. } \\
(\mathbf{m g})\end{array}$ & $\begin{array}{l}\text { Root } \\
\text { dry wt. } \\
(\mathbf{m g})\end{array}$ & $\begin{array}{l}\text { Total Plant } \\
\text { dry wt. } \\
(\mathbf{m g})\end{array}$ & $\begin{array}{l}\text { Shoot-Root } \\
\text { ratio }\end{array}$ \\
\hline $\mathrm{Ge}+\mathrm{R}$ & $83.58^{\mathrm{abc}}$ & $801.8^{\mathrm{bcd}}$ & $581.2^{\mathrm{ab}}$ & $1383.0^{\mathrm{a}}$ & $1.39^{\text {cde }}$ \\
$\mathrm{Gc}+\mathrm{R}$ & $107.40^{\mathrm{d}}$ & $1080.2^{\mathrm{e}}$ & $834.6^{\mathrm{c}}$ & $1914.8^{\mathrm{b}}$ & $1.29^{\mathrm{bcd}}$ \\
$\mathrm{Gi}+\mathrm{R}$ & $93.38^{\mathrm{bcd}}$ & $857.2^{\mathrm{cd}}$ & $535.3^{\mathrm{a}}$ & $1392.5^{\mathrm{a}}$ & $1.62^{\mathrm{e}}$ \\
$\mathrm{Gir}+\mathrm{R}$ & $80.28^{\mathrm{abc}}$ & $832.0^{\mathrm{bcd}}$ & $536.0^{\mathrm{a}}$ & $1368.0^{\mathrm{a}}$ & $1.56^{\mathrm{de}}$ \\
$\mathrm{Ge}-\mathrm{R}$ & $75.32^{\mathrm{ab}}$ & $630.0^{\mathrm{ab}}$ & $597.0^{\mathrm{ab}}$ & $1227.0^{\mathrm{a}}$ & $1.09^{\mathrm{abc}}$ \\
$\mathrm{Gc}-\mathrm{R}$ & $70.06^{\mathrm{a}}$ & $576.0^{\mathrm{a}}$ & $608.6^{\mathrm{ab}}$ & $1184.6^{\mathrm{a}}$ & $0.96^{\mathrm{a}}$ \\
$\mathrm{Gi}-\mathrm{R}$ & $84.44^{\mathrm{abc}}$ & $722.0^{\mathrm{abc}}$ & $600.9^{\mathrm{ab}}$ & $1322.9^{\mathrm{a}}$ & $1.21^{\mathrm{abc}}$ \\
$\mathrm{Gir}-\mathrm{R}$ & $67.84^{\mathrm{a}}$ & $704.0^{\mathrm{abc}}$ & $523.3^{\mathrm{a}}$ & $1227.3^{\mathrm{a}}$ & $1.37^{\text {cde }}$ \\
$\mathrm{N}+\mathrm{P}_{2}$ & $82.84^{\mathrm{abc}}$ & $674.0^{\mathrm{abc}}$ & $647.8^{\mathrm{ab}}$ & $1321.8^{\mathrm{a}}$ & $1.05^{\mathrm{ab}}$ \\
$\mathrm{R}+\mathrm{P}_{2}$ & $97.04^{\mathrm{cd}}$ & $977.6^{\mathrm{de}}$ & $910.0^{\mathrm{bc}}$ & $1687.6^{\mathrm{b}}$ & $1.38^{\text {cde }}$ \\
\hline
\end{tabular}

Means in each column followed by the same letter are not significantly different by Duncan's multiple range test $(P \leq 0.05, n=$ 5). Ge = Glomus etunicatum; $G c=$ Glomus clarum; Gi = Glomus intraradices; Gir - Gigaspora rosea $P_{2}=0.2 \mathrm{~mol} \mathrm{~m}^{-3} \mathrm{P} ; \mathrm{N}$ $=3 \mathrm{~mol} \mathrm{~m}^{-3} \mathrm{~N}$.

Table 2: Statistical analysis of the effect of arbuscular mycorrhizal fungi and Rhizobium on growth characteristics of $G$. sepium.

\begin{tabular}{|c|c|c|c|c|c|}
\hline Treatments & $\begin{array}{l}\text { Leaf area } \\
\left(\mathrm{cm}^{2} \text { plant }^{-1}\right)\end{array}$ & $\begin{array}{l}\text { Shoot } \\
\text { dry wt. } \\
\left.\text { (mg plant }^{-1}\right)\end{array}$ & $\begin{array}{l}\text { Root } \\
\text { dry wt. } \\
\left(\text { mg plant }^{-1}\right)\end{array}$ & $\begin{array}{l}\text { Total Plant } \\
\text { dry wt. } \\
\left(\text { mg plant }^{-1}\right) \\
\end{array}$ & $\begin{array}{l}\text { Shoot-Root } \\
\text { ratio }\end{array}$ \\
\hline \multicolumn{6}{|l|}{ Mycorrhiza } \\
\hline Glomus etunicatum & $79.45^{\mathrm{ab}}$ & $715.9^{\mathrm{a}}$ & $589.1^{\mathrm{a}}$ & $1305.0^{\mathrm{a}}$ & $1.24^{\mathrm{ab}}$ \\
\hline Glomus clarum & $88.73^{\mathrm{b}}$ & $828.1^{\mathrm{a}}$ & $721.6^{\mathrm{b}}$ & $1552.4^{\mathrm{b}}$ & $1.13^{\mathrm{a}}$ \\
\hline Glomus intraradices & $88.91^{\mathrm{b}}$ & $789.6^{\mathrm{a}}$ & $568.1^{\mathrm{a}}$ & $1357.7^{\mathrm{a}}$ & $1.42^{\mathrm{bc}}$ \\
\hline Gigaspora rosea & $74.06^{\mathrm{a}}$ & $768.0^{\mathrm{a}}$ & $529.6^{\mathrm{a}}$ & $1297.6^{\mathrm{a}}$ & $1.47^{\mathrm{c}}$ \\
\hline \multicolumn{6}{|l|}{ Rhizobium } \\
\hline Uninoculated (-R) & $74.42^{\mathrm{A}}$ & $658.0^{\mathrm{A}}$ & $582.5^{\mathrm{A}}$ & $1241.8^{\mathrm{A}}$ & $1.16^{\mathrm{A}}$ \\
\hline Inoculated $\quad(+\mathrm{R})$ & $91.16^{\mathrm{B}}$ & $892.8^{\mathrm{B}}$ & $621.8^{\mathrm{A}}$ & $1514.6^{\mathrm{B}}$ & $1.47^{\mathrm{B}}$ \\
\hline \multicolumn{6}{|l|}{$\operatorname{Pr}>\mathbf{F}$} \\
\hline Mycorrhiza (M) & 0.0057 & 0.0665 & 0.0003 & 0.0015 & 0.0019 \\
\hline Rhizobium (R) & $<0.0001$ & $<0.0001$ & 0.1778 & $<0.0001$ & $<0.0001$ \\
\hline $\mathrm{M} \times \mathrm{R}$ & 0.0093 & 0.0001 & 0.0055 & 0.0001 & 0.6738 \\
\hline $\mathrm{CV} \%$ & 12.43 & 11.76 & 14.98 & 10.73 & 15.26 \\
\hline
\end{tabular}

Means in each column followed by the same case letter are not significantly different by Duncan's multiple range test. 
Table 3: Nitrogen concentration (\% $\mathrm{N})$, content $(\mathrm{mg} \mathrm{N})$ and $\mathrm{N}$ fixed in $G$. sepium as influenced by different arbuscular mycorrhizal fungi with (+) and without (-) Rhizobium (R) inoculation and fertilised comparison plants at 12 weeks after planting

\begin{tabular}{|c|c|c|c|c|c|c|c|c|}
\hline \multirow[b]{2}{*}{ Treatment } & \multicolumn{2}{|c|}{ SHOOT } & \multicolumn{2}{|c|}{ ROOT } & \multicolumn{2}{|c|}{ TOTAL PLANT } & \multicolumn{2}{|c|}{ N FIXED } \\
\hline & $\% \mathbf{N}$ & mg $\mathbf{N}$ & $\% \mathrm{~N}$ & $\mathbf{m g ~} \mathbf{N}$ & $\% \mathbf{N}$ & mg N & Ndfa & pNdfa \\
\hline $\mathrm{Ge}+\mathrm{R}$ & $2.13^{\mathrm{cd}}$ & $16.77^{\mathrm{b}}$ & $2.02^{\mathrm{c}}$ & $11.51^{\mathrm{b}}$ & $2.08^{\mathrm{bcd}}$ & $28.29^{\mathrm{b}}$ & $18.98^{\mathrm{a}}$ & $66.4^{\mathrm{a}}$ \\
\hline $\mathrm{Gc}+\mathrm{R}$ & $1.92^{\mathrm{bc}}$ & $20.76^{\mathrm{b}}$ & $1.80^{\mathrm{b}}$ & $15.00^{\mathrm{d}}$ & $1.86^{\mathrm{b}}$ & $35.76^{\mathrm{c}}$ & $26.46^{\mathrm{a}}$ & $73.6^{\mathrm{a}}$ \\
\hline $\mathrm{Gi}+\mathrm{R}$ & $2.29^{\mathrm{d}}$ & $19.64^{\mathrm{b}}$ & $2.29^{\mathrm{d}}$ & $12.19^{\mathrm{bc}}$ & $2.29^{\mathrm{d}}$ & $31.83^{b c}$ & $22.53^{\mathrm{a}}$ & $70.7^{\mathrm{a}}$ \\
\hline Gir + R & $2.07^{\mathrm{cd}}$ & $17.11^{\mathrm{b}}$ & $2.13^{\text {cd }}$ & $11.46^{\mathrm{b}}$ & $2.09^{\mathrm{cd}}$ & $28.57^{\mathrm{b}}$ & $19.27^{\mathrm{a}}$ & $67.3^{\mathrm{a}}$ \\
\hline $\mathrm{Ge}-\mathrm{R}$ & $1.62^{\mathrm{a}}$ & $10.22^{\mathrm{a}}$ & $1.17^{\mathrm{a}}$ & $6.88^{\mathrm{a}}$ & $1.40^{\mathrm{a}}$ & $17.10^{\mathrm{a}}$ & - & \\
\hline Gc $-\mathrm{R}$ & $1.68^{\mathrm{ab}}$ & $9.63^{\mathrm{a}}$ & $1.26^{\mathrm{a}}$ & $7.58^{\mathrm{a}}$ & $1.46^{\mathrm{a}}$ & $17.21^{\mathrm{a}}$ & - & \\
\hline $\mathrm{Gi}-\mathrm{R}$ & $1.56^{\mathrm{a}}$ & $11.26^{\mathrm{a}}$ & $1.19^{\mathrm{a}}$ & $7.15^{\mathrm{a}}$ & $1.39^{\mathrm{a}}$ & $18.41^{\mathrm{a}}$ & - & \\
\hline Gir - R & $1.65^{\mathrm{ab}}$ & $11.54^{\mathrm{a}}$ & $1.29^{\mathrm{a}}$ & $6.71^{\mathrm{a}}$ & $1.49^{\mathrm{a}}$ & $18.25^{\mathrm{a}}$ & - & \\
\hline $\mathrm{N}+\mathrm{P}_{2}$ & $1.70^{\mathrm{ab}}$ & $11.48^{\mathrm{a}}$ & $1.13^{\mathrm{a}}$ & $7.32^{\mathrm{a}}$ & $1.42^{\mathrm{a}}$ & $18.80^{\mathrm{a}}$ & - & \\
\hline $\mathrm{R}+\mathrm{P}_{2}$ & $2.04^{\mathrm{cd}}$ & $20.10^{\mathrm{b}}$ & $1.99^{\mathrm{c}}$ & $14.07^{\mathrm{cd}}$ & $2.02^{\mathrm{bc}}$ & $34.18^{\mathrm{bc}}$ & $24.88^{\mathrm{a}}$ & $70.2^{\mathrm{a}}$ \\
\hline
\end{tabular}

Means in each column followed by the same letter are not significantly different by Duncan's multiple range test $(P \leq 0.05, n=$ 5). Ge = Glomus etunicatum; Gc = Glomus clarum; Gi = Glomus intraradices; Gir $=$ Gigaspora rosea $P_{2}=0.2 \mathrm{~mol} \mathrm{~m}^{-3} P$ : $N$ $=3 \mathrm{~mol} \mathrm{~m} \mathrm{~m}^{-3} \mathrm{~N}$. Ndfa = amount of $N$ fixed $(\mathrm{mg}) ; \mathrm{pNdfa}=$ proportion of $N$ fixed (\%).

significant for both mycorrhiza and Rhizobium (Table 2).

Leaf area as an index of growth followed a similar trend as the total plant dry matter produced, with the Rhizobium- inoculated mycorrhizal plants recorded larger leaf area than the Rhizobium-uninoculated mycorrhizal plants (Table 1). $\mathrm{Gc}+\mathrm{R}$ plants had significantly greater leaf area $\left(107.4 \mathrm{~cm}^{2}\right)$ than those of $\mathrm{Ge}+\mathrm{R}\left(83.6 \mathrm{~cm}^{2}\right)$ and Gir+R $\left(80.3 \mathrm{~cm}^{2}\right)$ but statistically similar to those of $\mathrm{Gi}+\mathrm{R}\left(93.4 \mathrm{~cm}^{2}\right)$ and the Rhizobiuminoculated, non-mycorrhizal comparison plants $\left(\mathrm{R}+\mathrm{P}_{2}\right)\left(97 \mathrm{~cm}^{2}\right)$. Main effects due to mycorrhiza or Rhizobium and their interaction were highly significant (Table 2).

Nodulation assessed by the number of nodules produced per plant was statistically similar for the Rhizobium- inoculated mycorrhizal treatments but differed significantly from the Rhizobium- inoculated, non-mycorrhizal comparison treatment $\left(\mathrm{R}+\mathrm{P}_{2}\right) . \mathrm{R}+\mathrm{P}_{2}$ plants produced the highest number of nodules (937 nodules plant $\left.{ }^{-1}\right)$, approximately thirty percent more than the Rhizobium-inoculated, mycorrhizal treatments. Between the AM fungi, Glomus clarum recorded the highest nodulation (648 nodules plant ${ }^{-1}$ ) and Glomus intraradices the lowest (526 nodules plant $^{-1}$ ).

Nitrogen concentration $(\% \mathrm{~N})$ and content $(\mathrm{mg} \mathrm{N})$ of Gliricidia sepium as influenced by mycorrhiza and/or Rhizobium and the comparison treatments are presented in Table 3. Rhizobium inoculation significantly increased $\mathrm{N}$ concentration and content over non-Rhizobium-inoculated mycorrhizal plants (supplied with $3 \mathrm{~mol} \mathrm{~m}^{-3} \mathrm{~N}$ ). Gc+R plants accumulated the highest total $\mathrm{N}$ content but this did not differ significantly from those of $\mathrm{Gi}+\mathrm{R}$ and the Rhizobium-inoculated, non-mycorrhizal comparison treatment $\left(\mathrm{R}+\mathrm{P}_{2}\right)$. Nitrogen concentration and content did not differ between the 
uninoculated mycorrhizal treatment and the nonsymbiotic comparison plants $\left(\mathrm{N}+\mathrm{P}_{2}\right)$. Statistical analyses of partitioning the effect of mycorrhiza and Rhizobium on $\mathrm{N}$ accumulation indicate significant differences in root $\mathrm{N}$ concentration and total $\mathrm{N}$ content (Table 4). The proportion (\%) and amount $(\mathrm{mg} \mathrm{N})$ of nitrogen fixed (total $\mathrm{N}$ seed N) was statistically similar in all Rhizobium - inoculated treatments (Table 3). However, $\mathrm{Gc}+\mathrm{R}$ plants recorded the highest dinitrogen fixation (26.46 $\mathrm{mg} \mathrm{N}$ ) and Gir+R, the least (19.27 mg N).

Phosphorus uptake differed significantly between the treatments (Table 5). Gc+R treatments accumulated significantly more $\mathrm{P}$ than the other Rhizobium- inoculated mycorrhizal treatments $(\mathrm{Ge}+\mathrm{R}, \mathrm{Gi}+\mathrm{R}$, and $\mathrm{Gir}+\mathrm{R})$ but were statistically similar to Rhizobium- inoculated, nonmycorrhizal comparison treatment $\left(\mathrm{R}+\mathrm{P}_{2}\right)$. In- oculation with Glomus clarum significantly increased $\mathrm{P}$ content and concentration in all plant parts. Gigaspora rosea was least effective in promoting phosphorus uptake in test tree seedling (Table 6).

Shoot phosphorus to nitrogen ratio (P: N) was statistically different between individual treatments (Table 5). Rhizobium- inoculated mycorrhizal plants had a lower ratio compared to the Rhizobium- uninoculated treatments. Glomus etunicatum and Gigaspora rosea had significantly lower ratio than Glomus clarum and Glomus intraradices and also Rhizobium inoculation achieved lower ratio than non-Rhizobium inoculated plants supplied with mineral nitrogen (Table $6)$.

Mycorrhizal root infection varied statistically between the AM fungal species (Table 7). Plants

Table 4: Statistical analysis of the effect of arbuscular mycorrhizal fungi and Rhizobium on nitrogen concentration $(\% \mathrm{~N})$ and content $(\mathrm{mg} \mathrm{N})$ of $G$. sepium at 12 weeks after planting

\begin{tabular}{lcccccc}
\hline & \multicolumn{2}{c}{ SHOOT } & \multicolumn{2}{c}{ ROOT } & TOTAL PLANT \\
Treatment & \% N & mg N & \% N & mg N & \% N & mg N \\
\hline Mycorrhiza & & & & & & \\
Glomus etunicatum & $1.87^{\mathrm{a}}$ & $13.50^{\mathrm{a}}$ & $1.59^{\mathrm{ab}}$ & $9.19^{\mathrm{a}}$ & $1.74^{\mathrm{a}}$ & $22.69^{\mathrm{a}}$ \\
Glomus clarum & $1.80^{\mathrm{a}}$ & $15.19^{\mathrm{a}}$ & $1.53^{\mathrm{a}}$ & $11.29^{\mathrm{a}}$ & $1.67^{\mathrm{a}}$ & $26.49^{\mathrm{b}}$ \\
Glomus intraradices & $1.93^{\mathrm{a}}$ & $15.45^{\mathrm{a}}$ & $1.74^{\mathrm{b}}$ & $9.67^{\mathrm{a}}$ & $1.84^{\mathrm{a}}$ & $25.12^{\mathrm{ab}}$ \\
Gigaspora rosea & $1.86^{\mathrm{a}}$ & $14.32^{\mathrm{a}}$ & $1.71^{\mathrm{b}}$ & $9.08^{\mathrm{a}}$ & $1.79^{\mathrm{a}}$ & $23.41^{\mathrm{a}}$ \\
& & & & & & \\
Rhizobium & & & & & & \\
Uninoculated (-R) & $1.63^{\mathrm{A}}$ & $10.66^{\mathrm{A}}$ & $1.23^{\mathrm{A}}$ & $7.08^{\mathrm{A}}$ & $1.44^{\mathrm{A}}$ & $17.74^{\mathrm{A}}$ \\
Inoculated (+R) & $2.10^{\mathrm{B}}$ & $18.57^{\mathrm{B}}$ & $2.06^{\mathrm{B}}$ & $12.54^{\mathrm{B}}$ & $2.08^{\mathrm{B}}$ & $31.11^{\mathrm{B}}$ \\
& & & & & & \\
Pr >F & & & & & & \\
Mycorrhiza (M) & 0.5484 & 0.1312 & 0.0181 & 0.0017 & 0.1235 & 0.0196 \\
Rhizobium (R) & $<0.0001$ & $<0.0001$ & $<0.0001$ & $<0.0001$ & $<0.0001<0.0001$ \\
M x R & 0.0652 & 0.0191 & 0.0047 & 0.0674 & 0.0188 & 0.0104 \\
CV\% & & & & & & \\
\hline
\end{tabular}

Means in each column followed by the same case letter are not significantly different by Duncan's multiple range test 
Table 5: Phosphorus concentration (\%P), content (mg P) and P:N ratio of $G$. sepium as influenced by different arbuscular mycorrhizal fungi with (+) and without (-) Rhizobium (R) inoculation and fertilised comparison plants at 12 weeks after planting

\begin{tabular}{llcccccc}
\hline & \multicolumn{2}{c}{ SHOOT } & \multicolumn{2}{c}{ ROOT } & \multicolumn{2}{c}{ TOTAL PLANT } & \multicolumn{2}{c}{ SHOOT } \\
Treatment & \% & mg P & \% P & mg P & \% P & mg P & P:N ratio \\
\hline $\mathrm{Ge}+\mathrm{R}$ & $0.25^{\mathrm{a}}$ & $2.00^{\mathrm{a}}$ & $0.37^{\mathrm{bc}}$ & $2.17^{\mathrm{abc}}$ & $0.30^{\mathrm{ab}}$ & $4.17^{\mathrm{a}}$ & $0.118^{\mathrm{a}}$ \\
$\mathrm{Gc}+\mathrm{R}$ & $0.35^{\mathrm{bcd}}$ & $3.82^{\mathrm{b}}$ & $0.58^{\mathrm{f}}$ & $4.85^{\mathrm{e}}$ & $0.45^{\mathrm{ef}}$ & $8.67^{\mathrm{d}}$ & $0.184^{\mathrm{bc}}$ \\
$\mathrm{Gi}+\mathrm{R}$ & $0.34^{\mathrm{abc}}$ & $2.94^{\mathrm{ab}}$ & $0.37^{\mathrm{bc}}$ & $2.00^{\mathrm{abc}}$ & $0.35^{\mathrm{cd}}$ & $4.94^{\mathrm{ab}}$ & $0.150^{\mathrm{ab}}$ \\
$\mathrm{Gir}+\mathrm{R}$ & $0.24^{\mathrm{a}}$ & $2.05^{\mathrm{a}}$ & $0.30^{\mathrm{ab}}$ & $1.63^{\mathrm{ab}}$ & $0.27^{\mathrm{a}}$ & $3.68^{\mathrm{a}}$ & $0.118^{\mathrm{a}}$ \\
$\mathrm{Ge}-\mathrm{R}$ & $0.33^{\mathrm{abc}}$ & $2.12^{\mathrm{a}}$ & $0.35^{\mathrm{bc}}$ & $2.16^{\mathrm{abc}}$ & $0.34^{\mathrm{bc}}$ & $4.28^{\mathrm{a}}$ & $0.206^{\mathrm{c}}$ \\
$\mathrm{Gc}-\mathrm{R}$ & $0.36^{\mathrm{bcd}}$ & $2.10^{\mathrm{a}}$ & $0.43^{\mathrm{cd}}$ & $2.71^{\mathrm{bc}}$ & $0.40^{\mathrm{de}}$ & $4.81^{\mathrm{ab}}$ & $0.214^{\mathrm{c}}$ \\
$\mathrm{Gi}-\mathrm{R}$ & $0.44^{\mathrm{de}}$ & $3.15^{\mathrm{ab}}$ & $0.38^{\mathrm{bc}}$ & $2.31^{\mathrm{abc}}$ & $0.41^{\mathrm{e}}$ & $5.46^{\mathrm{ab}}$ & $0.278^{\mathrm{d}}$ \\
$\mathrm{Gir}-\mathrm{R}$ & $0.29^{\mathrm{ab}}$ & $2.06^{\mathrm{a}}$ & $0.26^{\mathrm{a}}$ & $1.35^{\mathrm{a}}$ & $0.28^{\mathrm{a}}$ & $3.41^{\mathrm{a}}$ & $0.176^{\mathrm{bc}}$ \\
$\mathrm{N}+\mathrm{P}_{2}$ & $0.52^{\mathrm{e}}$ & $3.52^{\mathrm{b}}$ & $0.47^{\mathrm{de}}$ & $3.03^{\mathrm{cd}}$ & $0.50^{\mathrm{f}}$ & $6.55^{\mathrm{bc}}$ & $0.304^{\mathrm{d}}$ \\
$\mathrm{R}+\mathrm{P}_{2}$ & $0.42^{\mathrm{cd}}$ & $4.32^{\mathrm{b}}$ & $0.54^{\mathrm{ef}}$ & $3.96^{\mathrm{de}}$ & $0.48^{\mathrm{f}}$ & $8.19^{\mathrm{cd}}$ & $0.204^{\mathrm{c}}$ \\
\hline
\end{tabular}

Means in each column followed by the same letter are not significantly different by Duncan's multiple range test $(P \leq 0.05, n=$ 5). $G e=$ Glomus etunicatum; $G c=$ Glomus clarum; $G i=$ Glomus intraradices; Gir $=$ Gigaspora rosea $P_{2}=0.2 \mathrm{~mol} \mathrm{~m}^{-3} \mathrm{P}$; $N=3 \mathrm{~mol} \mathrm{~m}^{-3} \mathrm{~N}$.

Table 6: Statistical analysis of the effect of arbuscular mycorrhizal fungi and Rhizobium on phosphorus concentration (\% P), content (mg P), and P:N ratio of $G$. sepium at 12 weeks after planting

\begin{tabular}{|c|c|c|c|c|c|c|c|}
\hline \multirow[b]{2}{*}{ Treatment } & \multicolumn{2}{|c|}{ SHOOT } & \multicolumn{2}{|c|}{ ROOT } & \multicolumn{2}{|c|}{ TOTAL PLANT } & \multirow{2}{*}{$\begin{array}{c}\text { SHOOT P: N } \\
\text { ratio }\end{array}$} \\
\hline & $\% \mathbf{P}$ & mg P & $\% \mathbf{P}$ & mg P & $\% \mathbf{P}$ & $\mathbf{m g} \mathbf{P}$ & \\
\hline \multicolumn{8}{|l|}{ Mycorrhiza } \\
\hline Glomus etunicatum & $0.29^{\mathrm{a}}$ & $2.06^{\mathrm{a}}$ & $0.36^{\mathrm{b}}$ & $2.17^{\mathrm{b}}$ & $0.32^{\mathrm{b}}$ & $4.23^{\mathrm{a}}$ & $0.162^{\mathrm{a}}$ \\
\hline Glomus clarum & $0.36^{\mathrm{b}}$ & $2.96^{\mathrm{b}}$ & $0.51^{\mathrm{c}}$ & $3.78^{\mathrm{c}}$ & $0.43^{\mathrm{d}}$ & $6.74^{\mathrm{c}}$ & $0.199^{\mathrm{b}}$ \\
\hline Glomus intraradices & $0.39^{\mathrm{b}}$ & $3.05^{\mathrm{b}}$ & $0.38^{\mathrm{b}}$ & $2.15^{\mathrm{b}}$ & $0.38^{\mathrm{c}}$ & $5.20^{\mathrm{b}}$ & $0.214^{\mathrm{b}}$ \\
\hline Gigaspora rosea & $0.27^{\mathrm{a}}$ & $2.06^{\mathrm{a}}$ & $0.28^{\mathrm{a}}$ & $1.49^{\mathrm{a}}$ & $0.27^{\mathrm{a}}$ & $3.55^{\mathrm{a}}$ & $0.147^{\mathrm{a}}$ \\
\hline \multicolumn{8}{|l|}{ Rhizobium } \\
\hline Uninoculated (-R) & $0.36^{\mathrm{B}}$ & $2.36^{\mathrm{A}}$ & $0.36^{\mathrm{A}}$ & $2.13^{\mathrm{A}}$ & $0.36^{\mathrm{A}}$ & $4.49^{\mathrm{A}}$ & $0.219^{\mathrm{B}}$ \\
\hline Inoculated $\quad(+R)$ & $0.30^{\mathrm{A}}$ & $2.70^{\mathrm{A}}$ & $0.41^{\mathrm{B}}$ & $2.66^{\mathrm{B}}$ & $0.34^{\mathrm{A}}$ & $5.37^{\mathrm{B}}$ & $0.143^{\mathrm{A}}$ \\
\hline \multicolumn{8}{|l|}{$\operatorname{Pr}>\mathbf{F}$} \\
\hline Mycorrhiza (M) & 0.0001 & 0.0004 & $<0.0001$ & $<0.0001$ & $<0.0001$ & $<0.0001$ & $<0.0001$ \\
\hline Rhizobium (R) & 0.0024 & 0.0790 & 0.0129 & 0.0161 & 0.2510 & 0.0047 & $<0.0001$ \\
\hline$M \times R$ & 0.3336 & 0.0028 & 0.0408 & 0.0010 & 0.0211 & $<0.0001$ & 0.0069 \\
\hline $\mathrm{CV} \%$ & 17.79 & 23.94 & 15.53 & 27.49 & 11.54 & 18.57 & 16.17 \\
\hline
\end{tabular}

Means in each column followed by the same case letter are not significantly different by Duncan's multiple range test.

62 Journal of Science and Technology, Vol. 28, No. 2, August, 2008 
Table 7: Percentage root infection of $G$. sepium by different arbuscular mycorrhiza with (+) and without (-) Rhizobium (R) inoculation at 12 weeks after planting.

\begin{tabular}{lccl}
\hline $\begin{array}{l}\text { Arbuscular } \\
\text { Mycorrhiza } \\
\text { Fungus }\end{array}$ & \multicolumn{2}{l}{ Percentage (\%) root infection } & $\begin{array}{l}\text { Main } \\
\text { Effect } \\
\text { MEAN }\end{array}$ \\
\hline $\begin{array}{l}\text { Glomus etunicatum } \\
\text { Glomus clarum }\end{array}$ & $77.4 \pm 4.2^{\mathrm{c}}$ & $35.9 \pm 2.8^{\mathrm{ab}}$ & $56.6 \pm 2.7^{\mathrm{B}}$ \\
Glomus intraradices & $96.4 \pm 1.8^{\mathrm{d}}$ & $92.2 \pm 0.9^{\mathrm{cd}}$ & $94.3 \pm 2.7^{\mathrm{C}}$ \\
Gigaspora rosea & $98.9 \pm 0.5^{\mathrm{d}}$ & $83.2 \pm 4.4^{\mathrm{cd}}$ & $91.1 \pm 2.7^{\mathrm{C}}$ \\
Main Effect & $32.8 \pm 7.8^{\mathrm{a}}$ & $45.3 \pm 3.0^{\mathrm{b}}$ & $39.0 \pm 2.7^{\mathrm{A}}$ \\
MEAN & & & \\
\hline
\end{tabular}

Means \pm SE sharing the same case letter are not statistically different by Duncan's multiple range test $(P \leq 0.05 n=5)$.

inoculated with Glomus clarum and Glomus intraradices significantly achieved higher root colonization than Glomus etunicatum and $\mathrm{Gi}$ gaspora rosea. Consistently, lower root colonization was recorded in plants inoculated with Gigaspora rosea with and without Rhizobium. Rhizobium inoculation reduced root colonization by all the Glomus species except Gigaspora rosea. A highly significant $(\mathrm{P}<0.001)$ interaction between mycorrhiza and Rhizobium was observed for mycorrhiza colonization of roots.

\section{DISCUSSION}

Although AM fungi are not host specific, quantitative differences in growth, colonization and nutrient uptake have been observed in this study. AM fungi differed in their effectiveness in enhancing growth of Gliricidia sepium. Host plant growth was significantly increased by inoculation with Glomus clarum (Gc) (Table 2). AM fungal inoculation has been shown to significantly stimulate dry matter accumulation in Gliricidia sepium (Habte and Turk, 1991) and in Samanea saman (Syn. Albizia saman) (Rahman et al., 2004). Aziz and Habte (1989b) investigating the influence of three Glomus spp on the growth of Leucaena leucocephala in a tropical phosphorus-fixing soil, observed that mycorrhizal effectiveness and the greatest AM colonization occurred when soil was inoculated with Glomus aggregatum, followed by Glomus mosseae and Glomus etunicatum Berker and Gerd. Similarly, Dela Cruz et al. (1988), Paulino et al. (1992), Costa et al. (1992), and Cardoso and Kuyper (2006) reported differences in AM fungal effectiveness when tree legumes were grown in association with various AM fungal species.

Dual inoculation with AM fungi and Rhizobium was consistently effective in promoting host plant growth over uninoculated mycorrhizal plants (Table 1) which reflected in increases in different plant parameters such as leaf area, shoot and root dry weights, total plant biomass produced, and shoot-root ratio. Growth enhancement by dual inoculation has been observed in Sesbania grandiflora (Aziz and Habte, 1990), Leucaena leucocephala (Manjunath et al., 1984), Acacia auriculiformis and Acacia mangium (Dela Cruz et al., 1990); Acacia nilotica (Michelsen and Rosendahl, 1990) and Dalbergia sissoo (Verma et al., 1996).

Glomus clarum in association with Rhizobium $(\mathrm{Gc}+\mathrm{R})$ was the most efficient symbiosis, achieving significantly higher dry matter yield than $\mathrm{Gi}+\mathrm{R}, \mathrm{Ge}+\mathrm{R}$, and Gir+R. The growth enhance- 
ment of plants inoculated with Gc+R may be attributed to the improved nutrient accumulation in total $\mathrm{N}$ (Table 3, 4), total P uptake (Table 5, 6) which might be linked to good nodulation and high mycorrhizal colonization (Table 7). AM infection was positively correlated with $\mathrm{P}$ concentration $(\% \mathrm{P})(\mathrm{r}=0.74, \mathrm{P}<0.01)$, and $\mathrm{P}$ content $(\mathrm{mg} P) \quad(\mathrm{r}=0.52, \mathrm{P}<0.01)$. Increased uptake of nutrients especially phosphorus has been reported as the most important mechanism through which AM fungi improve legume tree growth and nutrition (Mosse, 1986; Manjunath and Habte, 1988; Barea et al., 1990; Azcón et al., 1991; Rahman et al., 2004) through P-mediated effect of the mycorrhiza on nitrogen fixation (Barea and Azcón-Aquilar, 1983; Mortimer et al., 2008)

Differences in efficiency among AM fungi might be due to their compatibility with the Rhizobium strain used since uninoculated mycorrhizal plants (supplied with $3 \mathrm{~mol} \mathrm{~m}^{-3} \mathrm{~N}$ as $\mathrm{KNO}_{3}$ ) recorded statistically similar total plant dry weight (Table 2). Azcón et al., (1991) pointed out that plant response depends on the particular combination of Rhizobium strain and Glomus species (or isolates), suggesting specific compatibilities between the host and microorganisms associated in the tripartite symbiosis (Ruiz-Lozano and Azcón, 1993). There are also reports indicating that Rhizobium strains exhibited a different degree of growth enhancement with different AM fungi (Bayne and Bethlenfalvay, 1987; Ianson and Linderman, 1991, 1993). This finding further indicates that nitrogen source was a decisive factor rather than the presence of the fungus.

The differences in growth between Rhizobiuminoculated and Rhizobium- uninoculated mycorrhizal treatments may be due to nitrogen being a limiting factor for growth of nonRhizobium plants as revealed by their higher P: $\mathrm{N}$ ratio (Table 5,6 ). Shoot-root ratio (Table 1) was higher in Rhizobium- inoculated mycorrhizal plants than Rhizobium- uninoculated mycorrhizal plants due to improved mineral nutri- tion particularly $\mathrm{N}$ (through nitrogen fixation) as indicated by Smith, (1982). Plants deficient in N and $\mathrm{P}$ have been reported to invest more assimilate in roots rather than shoot (Clarkson, 1985) which explains the lower shoot-root ratio observed in the Rhizobium- uninoculated mycorrhizal plants. This according to Föhse et al., (1988) is an adaptation of plants to improve their nutrient uptake efficiency when an essential nutrient is limiting.

Root colonization by Glomus clarum with and without Rhizobium inoculation ( $\mathrm{Gc}+\mathrm{R}, \mathrm{Gc}-\mathrm{R})$ was similar, but the plants differed significantly in growth characteristics (Table 1). This may be attributed to the nitrogen stress observed in Gc-R treatment. Gc-R plants had significantly lower total $\mathrm{N}$ concentration and content (Table 3) and higher P: $\mathrm{N}$ ratio $(0.214)$ compared to the lower ratio (0.184) found in $\mathrm{Gc}+\mathrm{R}$ treatment. Earlier studies have shown that plant $\mathrm{N}$ stress, like $\mathrm{P}$ stress promotes root colonization by AM fungi (Sylvia and Neal, 1990). This might explain the high root colonization but poor growth enhancement found in the Gc-R treatment.

The low P uptake by Gigaspora rosea infected plants (Table 5, 6) but which accumulated statistically similar dry weights to those infected with Glomus etunicatum and Glomus intraradices might suggest some other non-nutritional functions. Miller and Jastrow, (1992), reported that there may be specialization among AM fungi in functions affecting plant vs. soil nutrition and stated that AM fungal species of the genus $G i$ gaspora appear to favour fluxes of carbon compounds from plants to the soil biota, resulting ultimately in enhanced soil aggregation while Glomus species tend to favour plant growth through improved nutrition.

The higher total dry matter produced, $\mathrm{N}$ accumulated and $\mathrm{P}$ uptake of Rhizobium- inoculated Glomus clarum plants (Gc+R) than the Rhizobium - inoculated, non-mycorrhizal comparison plants $\left(\mathrm{R}+\mathrm{P}_{2}\right)$ attest to the importance of some AM fungi for legume tree growth and nutrition. This also

64 Journal of Science and Technology, Vol. 28, No. 2, August, 2008 
suggests that in nutrient deficient soils, effective mycorrhizal fungus could be used to promote growth and nitrogen fixation in $\mathrm{N}_{2}$-fixing trees. It was also observed that Rhizobium- uninoculated mycorrhizal treatments (Ge-R, Gc-R, Gi-R, Gir-R) obtained comparable total dry weight to the non-symbiotic comparison treatment $\left(\mathrm{N}+\mathrm{P}_{2}\right)$ which further indicates that AM fungi could be used to establish or improve growth of plants in $\mathrm{N}$ and $\mathrm{P}$ deficient soils.

\section{CONCLUSION}

The study has shown that there is significant variation in the efficiency of AM fungi to enhance growth and nutrient uptake of Gliricidia sepium when in association with an efficient Rhizobium strain. Such differences should be explored and used in absence of adequate mineral nutrition (particularly $\mathrm{P}$ deficiency) to establish, improve growth and nitrogen fixation of $G$. sepium and other nitrogen-fixing trees.

\section{REFERENCES}

Azcón, R. and Barea, J.M. (1992). Nodulation, $\mathrm{N}_{2}$ fixation $\left({ }^{15} \mathrm{~N}\right)$ and $\mathrm{N}$ nutrition relationships in mycorrhizal or phosphate-amended alfalfa plants. Symbiosis 12: 33-41.

Azcón, R., Rubio, R. and Barea, J.M. (1991). Selective interactions between different species of mycorrhizal fungi and Rhizobium meliloti strains, and their effect on growth, $\mathrm{N}_{2}$ fixation $\left({ }^{15} \mathrm{~N}\right)$ and nutrition of Medicago sativa L. New Phytologist 117: 399-404.

Aziz, T. and Habte, M. (1989a). Response of Sesbania grandiflora to pre-infection with Glomus aggregatum in an oxisol. Nitrogen Fixing Tree Research Reports 7: 117-119.

Aziz, T. and Habte, M. (1989b). Influence of inorganic $\mathrm{N}$ on mycorrhizal activity, nodulation and growth of Leucaena leucocephala in an oxisol subjected to simulated erosion. Soil Science and Plant Analysis 20: 239251.
Aziz, T. and Habte, M. (1985). Interaction of Leucaena with Glomus fasciculatum in a typical oxisol. Leucaena Research Reports 6: 97-98.

Aziz, T. and Habte, M. (1990). Growth of transplanted Sesbania grandiflora as affected by pre-infection of roots with rhizobia and VAM fungus. Nitrogen Fixing Tree Research Reports 8: 159-160.

Aziz, T. and Sylvia, D.M. (1993). Utilization of vesicular-arbuscular mycorrhizal fungi in the establishment of nitrogen-fixing trees. In: Symbioses of Nitrogen-Fixing Trees. Subba Rao, N.S. and Rodriguez-Barreuco, C. (eds). Oxford \& IBH Publishing Co. Pvt. Ltd., New Delhi. pp. 167-194.

Baker, A. (1992). A Study of the Tripartite Association Between Prosopis juliflora, Rhizobia and Vesicular Arbuscular Mycorrhizas. PhD Thesis, University of Dundee.

Barea, J.M., Azcón, R. and Azcón-Aquilar, C. (1992). Vesicular-arbuscular mycorrhizal

fungi in nitrogen-fixing systems. Methods in Microbiology 24: 391-416.

Barea, J.M. and Azcón-Aquilar, C. (1983). Mycorrhizas and their significances in nodulating nitrogen-fixation plants. Advances in Agronomy 36: 1-54.

Barea, J.M., Salamanca, C.P. and Herrera, M.A. (1990). The role of VA mycorrhiza at improving $\mathrm{N}_{2}$-fixation by woody legumes in arid zones. In: Fast Growing Trees and $\mathrm{Ni}$ trogen Fixing Trees. Werner, D. and Müller, P. (eds). Gustav Fisher-Verlag, Stuggart, Germany. pp. 303-311.

Bayne, H.G. and Bethlenfalvay, G.H. (1987). The Glycine-Glomus-Rhizobium Symbiosis IV. Interaction between the mycorrhizal and nitrogen-fixing endophytes. Plant, Cell and Environment 10: 607-612 
Cardoso, I.M.and Kuyper, T.W. (2006). Mycorrhizas and tropical soil fertility. Agriculture, Ecosystems and Environment 116: 7284.

Classen, V.P. and Zasoski, R.J. (1992). A containerised staining system for mycorrhizal roots. New Phytologist 121: 49-51.

Clarkson, D.T. (1985). Factors affecting mineral nutrient acquisition by plants. Annual Review of Plant Physiology 31: 239-298.

Costa, N. de L., Paulino, V.T., Veasey, E.A. and Leonidas, F. das C. (1992). Effect of vesicular-arbuscular mycorrhiza and rock phosphate fertilization on growth, nodulation and nitrogen and phosphorus uptake of Leucaena. Leucaena Research Reports 13: 10-12.

Dela Cruz, R.E., Lorilla, E.B. and Agganga, N.S. (1990). Growth of Acacia auriculiformis and Acacia mangium in marginal grassland in response to inoculation with VA mycorrhiza and/or Rhizobium. In: Fast Growing Trees and Nitrogen Fixing Trees. Werner, D. and Müller, P. (eds). Gustav Fischer Verlag. Stuttgart, New York. p. 321.

Dela Cruz, R.E., Manalo, M.Q., Aggangan, N.S. and Tambalo, J.D. (1988). Growth of three legume trees inoculated with VA mycorrhizal fungi and Rhizobium. Plant and Soil 108, 111-115.

Fitter, A.H. and Garbaye, J. (1994). Interactions between mycorrhizal fungi and other soil organisms. Plant and Soil 159: 123-132.

Fohse, D., Classen, N. and Jungk, A. (1988). Phosphorus efficiency of plants I. External and internal $\mathrm{P}$ requirement and $\mathrm{P}$ uptake efficiency of different plant species. Plant and Soil 110: 101-109.

Giovannetti, M. and Mosse, B. (1980). An evaluation of techniques for measuring ve- sicular-arbuscular mycorrhizal infection in roots. New Phytologist 84: 489-500.

Habte, M. and Aziz, T. (1985). Response of Sesbania to inoculation of soil with vesiculararbuscular mycorrhizal fungi. Applied and Environmental Microbiology 50: 701-703.

Habte, M. and Turk, D. (1991). Response of two species of Cassia and Gliricidia sepium to vesicular-arbuscular mycorrhizal infection. Communications in Soil Science and Plant Analysis 22(17-18): 1861-1872.

Harley, J.L. and Smith, S.E. (1983). Mycorrhizal Symbiosis. Academic Press, London.

Hayman, D.S. (1986). Mycorrhiza of nitrogen fixing legumes. MIRCEN Journal 2: 121145 .

Herrera, M.A., Salamanca, P. and Barea, J.M. (1993). Mycorrhizal associations and their functions in nodulating nitrogen-fixing trees. In: Symbioses of Nitrogen-Fixing Trees. Subba Rao, N.S. and Rodriguez-Barrueco, C. (eds). Oxford \& IBH Publishing Co. Pvt. Ltd., New Delhi. pp. 141-165.

Ianson, D.C. and Linderman, R.G. (1991). Variation in VA mycorrhiza strain interactions with Rhizobium on pigeon pea. In: Rhizosphere and Plant Growth. Keister, D.L. and Cregan, P.B. (eds). Kluwer Academic Publishers, Netherlands. pp. 371-372.

Ianson, D.C. and Linderman, R.G. (1993). Variation in response of nodulating pigeon pea (Cajanus cajan) to different isolates of mycorrhizal fungi. Symbiosis 15: 105-119.

Jacob-Neto, J. (1993). The Interaction of $\mathrm{H}^{+} / \mathrm{OH}^{-}$ Exchanges Between Roots and Rhizosphere with Plant Nutrition and Aluminium Effects. $\mathrm{PhD}$ Thesis, University of Dundee.

Koske, R.E. and Gemma, J.N. (1989). A modified procedure for staining roots to detect VA mycorrhizas. Mycological Research 92: 480505. 
Manjunath, A. and Bagyaraj, D.J. and Gowda, G. (1984). Dual inoculation with VA mycorrhiza and Rhizobium is beneficial to Leucaena. Plant and Soil 124: 7-13.

Manjunath, A. and Habte, M. (1988). Development of vesicular-arbuscular mycorrhizal infection and the uptake of immobile nutrition in Leucaena leucocephala. Plant and Soil 106: 97-103.

Manjunath, A., Hue, N.V. and Habte, M. (1989). Response of Leucaena leucocephala to vesicular-arbuscular mycorrhizal colonization and rock phosphate fertilization in an oxisol. Plant and Soil 114: 127-133.

Mason, P.A., Ingleby, K. and Munro, R.C. (1991). Techniques for endomycorrhizal research. In: Report on the ICRAF/ITE (AMSAL) Training Workshop on the Application of Soil Microorganisms for Tree and Crop Improvement. ICRAF, Nairobi.

Michelsen, A. and Rosendahl, S. (1990). The effect of VA mycorrhizal fungi, phosphorus and drought stress on the growth of Acacia nilotica and Leucaena leucocephala seedlings. Plant and Soil 124: 7-13.

Miller, R.M. and Jastrow, J.D. (1992). The role of mycorrhizal fungi in soil conservations. In: Mycorrhizae in Sustainable Agriculture. Bethlenfalvay, G.J. and Linderman, R.G. (eds). American Society of Agronomy (ASA) Special publication, No. 54. Madison, Wisconsin USA. pp. 29-44.

Mortimer, P.E., Perez-Fernandez, M.A. and Valentine, A.J. (2008). The role of arbuscular mycorrhizal colonization in Carbon and Nutient economy of the tripartite symbiosis with nodulated Phaseolus vulgaris. Soil Biology and Biochemistry 40; 1019-1027.

Mosse, B. (1986). Mycorrhiza in a sustainable agriculture. Biological Agriculture and Horticulture 3: 191-209.
Pascovsky, R.S., Bethlenfalvay, G.J. and Paul, E.A. (1986). Comparisons between phosphorus-fertilised and mycorrhizal plants. Crop Science 26: 151-156.

Pascovsky, S.R. and Fuller, G. (1986). Development of two endomycorrhizal symbiosis and comparison with phosphorus fertilization. Plant and Soil 95, 361-369.

Pasqualini, D., Uhlman, A. and Sturmer, S.L. (2007). Arbuscular mycorrhizal fungal communities influence growth and phosphorus concentration of woody plants species from Atlantic rain forest in South Brazil. Forest Ecology and Management 245 :148-155.

Paulino, V.T., Costa, N. de L. and Veasey, E.A. (1992). Response of Cajanus cajan to vesicular-arbuscular mycorrhizal inoculation. Nitrogen Fixing Tree Research Reports 10: 129-131.

Phillips, J.M. and Hayman, D.S. (1970). Improved procedures for clearing roots and staining parasitic and vesicular-arbuscular mycorrhizal fungi for rapid assessment of infection. Transactions of the British Mycological Society 55: 158-161.

Rahman M.S., Mridha, M.A.U., Huda, S.M.S., Haque, M.M. and Haque, S.M.S.(2004). Effects of fertilizers on nodulation and growth of Samanea saman Merr in presence of arbuscular mycorrhiza fungi at nursery level. In: Serraj, R. (Editor) Symbiotic Nitrogen Fixation-Prospect for Enhanced Application in Tropical Agriculture. Oxford \& IBH Publishing Co. Pvt. Ltd. New Delhi, India.

Roskoski, J.P., Pepper, I. and Pardo, E. (1986). Inoculation of leguminous trees with rhizobia and VA mycorrhizal fungi. Forest Ecology and Management 16: 57-68.

Ruiz-Lozano, J.M. and Azcon, R. (1993). Specificity and functional compatibility of VA mycorrhizal endophytes in association with 
Bradyrhizobium strains in Cicer arietinum. Symbiosis 15: 217-226.

Schenck, N.C. (1989). Interactions between herbaceous legumes and their associated rhizobia, mycorrhizae, pests and parasites. In: Advances in Legume Biology. Stirton, C.H. and Zarucchi, J.L. (eds). Monographs on Systematic Botany, Missouri Botanic Garden 29: 595-605.

Smith, S.E. (1982). In flow of phosphate into mycorrhizal and non-mycorrhizal plants of Trifolium subterraneum at different levels of soil phosphate. New Phytologist 90: 293303.

South, W.T. and Habte, M. (1985). The influence of starter nitrogen and mycorrhizal inoculation on the post-transplanting performance of Leucaena. Leucaena Research Reports 6: 95-96.
Stahl, P.D., Williams, S.E. and Christensen, M. (1988). Efficiency of native vesiculararbuscular mycorrhizal fungi after severe soil disturbance. New Phytologist 110: 347-354.

Sylvia, D.M. and Neal, L.H. (1990). Nitrogen affect the phosphorus response of VA mycorrhiza. New Phytologist 115, 303-310.

Vincent, J.M. (1970). A Manual for the Practical Study of Root Nodule Bacteria. International Biological Programme Handbook No. 15. Blackwell Scientific Publications Ltd., Oxford.

Vogel, A.I. (1989). Textbook of Quantitative Chemical Analysis. Jeffery, G.H., Bassett, J., Mendham, J. and Denney, R.C. (eds). Longman, Scientific and Technical, New York. 